\title{
Capillary Plasma
}

National Cancer Institute

\section{Source}

National Cancer Institute. Capillary Plasma. NCI Thesaurus. Code C132461.

Plasma that has been isolated from capillary blood. 